\title{
ЗНАЧЕННЯ ВАСПІНУ ТА ОМЕНТИНУ У РОЗВИТКУ ОЖИРІННЯ - ПРЕДИКТОРА СЕРЦЕВО-СУДИННИХ УСКЛАДНЕНЬ У ХВОРИХ НА ЦУКРОВИЙ ДІАБЕТ 2 ТИПУ*
}

\author{
Кравчун Н. O. ${ }^{1}$, Алхамід М. Х. ${ }^{1}$, Місюра К. В. ${ }^{1}$, Дунаева I. П. ${ }^{2}$, \\ Романова I. П. ${ }^{1}$, Чернявська I. В. ${ }^{1}$, Соколова С. С. ${ }^{1}$ \\ ${ }^{1}$ ДУ "Інститут проблем ендокринної патологї ім. В. Я. Данилевського НАМН Украӥни», \\ м. Харків, Україна; \\ ${ }^{2}$ Харківський національний медичний університет, м. Харків, Украӥна \\ vladimirovana59@gmail.com
}

Проблема зниження смертності від серцево-судинних захворювань залишаеться предметом особливої уваги сучасної медичної науки. Незважаючи на значні досягнення останніх десятиріч у вивченні патогенезу та оптимізації лікувальних і діагностичних підходів до серцево-судинних ускладнень вони залишаються причиною втрати працездатності, інвалідності та смертності у хворих на цукровий діабет (ЦД) 2 типу.

Добре відомо, що ожиріння, особливо вісцеральне, підвищуе ризик розвитку метаболічного синдрому (МC) та ЦД 2 типу [1]. Надлишкове накопичення вісцерального жиру призводить до змін у вивільненні біоактивних медіаторів. Велика кількість адипокінів модулюе чутливість до інсуліну, артеріального тиску, ліпідного та глюкозного обміну, запалення та атеросклерозу $[1,2]$.

Останніми роками суттево переглянута роль жирової тканини в організмі людини. Одним з важливих ефектів адипокінів, що продукуються жировою тканиною, вважаеться їх патогенетична участь в реалізації системного низькоінтенсивного запалення, яке сприяе розвитку і прогресуванню серцево-судинних захворювань, ЦД, ожиріння.

Натепер відома вже велика кількість гормонів жирової тканини, однак увага вчених прикута до так званих "нових» адипокінів, одними з яких є оментин та васпін.

Вищезазначені адипокіни нещодавно були відкриті як вісцеральні жироспецифічні секреторні протеїни і були посту-

* Роботу виконано в межах планової наукової тематики ДУ «Інститут проблем ендокринної патології ім. В. Я. Данилевського НАМН України» «Дослідити роль адипокінів в розвитку кардіоваскулярних ускладнень у хворих на цукровий діабет 2 типу з неалкогольною жировою хворобою печінки» (державний реєстраційний № 0116U007262).

Установою, що фінансуе дослідження, е НАМН України.

Автор гарантуе повну відповідальність за все, що опубліковано в статті.

Автор гарантуе відсутність конфлікту інтересів і власної фінансової зацікавленості при виконанні роботи та написанні статті.

Рукопис надійшов до редакції 17.07.2020. 
льовані, як ті, що відіграють значну роль у зв'язку між ожирінням і пов'язаними 3 ним метаболічними порушеннями (неалкогольною жировою хворобою печінки, синдромом полікістозних яєчників, обструктивним нічним апное та психічними розладами) [2-4].

Васпін був ідентифікований як адипокін з інсулінсенсибілізуючою дією, який на моделі ЦД 2 типу у щурів переважно секретуеться з вісцеральної жирової тканини [5]. Його введення тучним щурам поліпшувало толерантність до глюкози і чутливість до інсуліну [6].

Youn B. S. разом із співавторами у 2008 році показали, що підвищена концентрація васпіну у сироватці крові корелює зі ступенем ожиріння, параметрами порушення чутливості до інсуліну, а експресія мРНК цього адипокіну в жировій тканині пов'язана 3 метаболічними проявами ожиріння та рівнем глюкози у дорослих осіб [7].

Натепер доведено, що васпін може відігравати певну роль в патогенезі ЦД і ожиріння, однак тонкі механізми цього до кінця не відомі. Встановлено, що васпін в організмі людини виробляють жирова тканина, печінка, скелетні м'язи, підшлункова залоза та шкіра. В ряді проведених клінічних досліджень показано, що цей адипокін тісно взаємопов'язаний $з$ ожирінням, метаболізмом глюкози, ЦД 2 типу та інсулінорезистентністю, а концентрація васпіну [8-12] вказує на те, що може бути пов'язана 3 виникненням і розвитком атеросклерозу у хворих на ЦД [8-11, 13]. Проте серед людей похилого віку було проведено мало досліджень. Крім того, менше уваги приділялося взаємозв'язку між васпіном і діабетичними серцево-судинними ускладненнями. В дослідженні вчених з Каїрського Національного дослідного центру показано, що рівень васпіну був ймовірно вищим у пацієнтів, хворих на ЦД 2 типу, в порівнянні з особами контрольної групи і у пацієнтів з серцево-судинними захворюваннями порівняно з особами без серцево-судинних захворювань, а також встановлений його позитивний кореляційний взаємозв'язок з IMT та рівнями глюкози плазми натще, інсуліном та індексом інсулінорези- стентності - НОМА-IP. Підвищений рівень васпіну асоціювався з підвищенням ризику серцево-судинних захворювань в 1,7 рази $(\mathrm{P}=0,001$, або $=1,7,95 \%$ ДI = 1,21-2,39). За допомогою ROC-аналізу доведено, що васпін сироватки крові є незалежним біомаркером ризику розвитку серцево-судинних захворювань з чутливістю $94 \%$ і специфічністю $74 \%$. Отже вченими зроблено висновок, що циркулюючий васпін є потенційно новим незалежними біомаркером виникнення серцево-судинних захворювань за ЦД 2 типу [14, 15].

Щодо адипокіну оментину, то натепер доведено, що він є протизапальною молекулою, і таким чином переважно відіграє паракринну i аутокринну роль у підвищенні чутливості до інсуліну. Окрім того, нещодавні клінічні дослідження були зосереджені на визначенні впливу оментина на серцево-судинну систему. У цих дослідженнях показано, що вміст вищезазначеного циркулюючого адипокіну в крові мав зворотній кореляційний зв'язок з атеросклеротичними параметрами $[16,17]$. У ряді клінічних дослідженнях було доведено, що рівень оментину значно знижується у пацієнтів із МС та ЦД 2 типу [18, 19].

Результати низки клінічних досліджень показали, що рівні циркулюючого оментину знижуються при ожирінні, МС та ЦД 2 типу і зворотно корелюють зі ступенем ожиріння, показниками інсулінорезистентності та деякими метаболічними параметрами [20-25]. Дані ряду досліджень засвідчують, що зниження рівня оментину може бути асоційовано з виникненням та розвитком ішемічної хвороби серця (IXC) [26, 27].

Відповідно результатам досліджень, проведених протягом 2011-2014 рр., визначено, що рівень циркулюючого оментину знижується у пацієнтів з IXC [28, 29] і встановленим атеросклерозом сонних артерій [29], зроблені припущення, що концентрація оментину в плазмі може у деякій мірі відображати дисфункцію судин, особливо у пацієнтів із ЦД.

Moreno-Navarrete J. M. та співавтори продемонстрували, що концентрація циркулюючого оментину незалежно асоціюеться з параметрами ультразвукового досліджен- 
ня (УЗД) високої роздільної здатності плечової артерії навіть після контролю ожиріння, віку і запалення у осіб із порушеною толерантністю до глюкози. Було встановлено, що прозапальні цитокіни (фактор некрозу пухлин- $\alpha$ та інтерлейкін-6) зворотно пов'язані 3 концентрацією циркулюючого оментину. Правомірна інтерпретація цих результатів засвідчує зв'язок прозапальних станів у осіб із порушеною толерантністю до глюкози із зниженим рівнем оментину в результаті погіршення тонуса судин [30]. Доведено, що рівні циркулюючого оментину зворотно корелюють з товщиною інтима-медіа сонної артерії у практично здорових чоловіків та у пацієнтів із ЦД 2 типу [24, 31]. $\mathrm{Xu} \mathrm{T.} \mathrm{із} \mathrm{співавторами} \mathrm{продемонстрували,}$ що у пацієнтів з ішемічним інсультом із нестабільною бляшкою сонної артерії рівень сироваткового оментину був значно нижче у порівнянні з пацієнтами зі стабільною бляшкою. Вищезазначене засвідчуе, що оментин може являти собою біомаркер для прогнозування розвитку атеросклерозу з нестабільною бляшкою сонної артерії [21].

Үоо Н. Ј. та співавтори довели, що рівні сироваткового оментину у пацієнтів, хворих на ЦД 2 типу, були значно нижчі у порівнянні 3 особами із нормальним контролем рівня глюкози і був значно знижений у хворих на ЦД 2 типу та наявною каротидною бляшкою сонної артерії з урахуванням віку статі, індексу маси тіла, систолічного артеріального тиску, рівнів глюкози в крові натщесерце та показника холестерину ліпопротеїнів низької щільності, а також наявністю в анамнезі куріння та прийому лікарських засобів. Авторами зроблено висновок, що рівень циркулюючого оментину незалежно корелює 3 жорсткістю артерій і каротидними бляшками за наявності ЦД 2 типу [23]. На жаль, це дослідження включало обмежену вибірку і не було репрезентативним.

Цікаво, що Hayashi M. та співавтори теж досліджували зв'язок між рівнями оментину в плазмі та ендотеліальною фрункцією судин, що визначалася за результатами УЗД високої роздільної здатності плечової артерії у хворих на ЦД 2 типу. Так, було показано, що плазмові рівні оментину ма- ють позитивний кореляційний взаємозв'язок з параметрами УЗД високої роздільної здатності плечової артерії у підгрупах пацієнтів із ЦД 2 типу з високим ризиком серцево-судинних захворювань, таких як літній вік, порушення фрункції нирок або серцево-судинні захворювання в анамнезі. I навпаки, не було виявлено достовірної асоціації між оментином і параметрами УЗД високої роздільної здатності плечової артерії в підгрупах пацієнтів хворих на ЦД 2 типу з низьким ризиком серцево-судинних захворювань та у осіб контрольної групи без діабету. Останне продемонструвало, що рівень оментину в плазмі крові незалежно пов'язаний 3 функцією ендотелію в підгрупах пацієнтів хворих на ЦД 2 типу 3 підвищеним серцево-судинним ризиком. Ці результати засвідчують, що оментин безпосередньо стимулює фрункцію ендотелію у осіб із ЦД та фракторами ризику серцево-судинних захворювань [32] i може бути корисним біомаркером судинної дисфункції у хворих на ЦД 2 типу.

Встановлено, що оментин відіграє захисну роль при серцево-судинних захворюваннях. Так, кілька ліній доказів із досліджень на тваринах вказують на захисні ефекти оментину проти серцево-судинних ушкоджень через його дію на судинний ендотелій, гладком'язові клітини, макрофраги і кардіоміоцити [33-38]. Maruyama S. та співавтори показали, що оментин сприяє функціонуванню ендотеліальних клітин та реваскуляризації у відповідь на ішемію завдяки своїй здатності стимулювати сигнальний шлях Akt-eNOS [33]. Kataoka Y. із співавторами зазначили, що збільшення циркулюючого людського оментину за допомогою аденовірусних трансгенних систем надлишкової експресії до індукції ішемії призводить до зменшення ушкодження серця після реперфузії у щурів, як за допомогою АМР-активуючої протеїнкінази (AMPK), так і Akt-залежних механізмів [38]. Ці результати показують, що оментин може не тільки служити цінним біомаркером серцево-судинних ускладнень, але і може діяти як терапевтичний агент. Таким чином, підвищення рівня циркулюючого оментину може бути новою терапевтичною 
стратегією для лікування серцево-судинних захворювань у хворих на ЦД. Разом 3 тим, необхідні додаткові експериментальні дослідження і великомасштабні проспективні клінічні дослідження для з'ясування практичного впливу оментину на атеросклеротичний процес у пацієнтів, що хворіють на ЦД 2 типу.

Таким чином, на сучасному етапі біологічні і патофізіологічні ефекти васпіна й оментина в організмі людини до кінця не з'ясовані, а даних щодо їх прогностичнодіагностичного значення у хворих на ЦД
2 типу із серцево-судинної патологією на тлі ожиріння вкрай мало.

Все вищезазначене обумовлює доцільність поглибленого дослідження значення гормонів васпіну й оментину в розвитку серцево-судинних ускладнень у хворих на ЦД 2 типу на тлі ожиріння.

Метою дослідження стало з'ясування ролі адипокінів васпіну та оментину в розвитку метаболічних порушень, а саме, ожиріння різного ступеню, як предиктора серцево-судинних ускладнень у хворих на ЦД 2 типу.

\section{МАТЕРІАЛИ ТА МЕТОДИ}

В дослідження були включені 75 паціентів (39 чоловіків та 36 жінок) хворих на ЦД 2 типу з надлишковою масою тіла (надлМТ) та ожирінням (ОЖ) різного ступеня. Вік пацієнтів в середньому становив $(67,00 \pm 1,06)$ років, зріст - $(170,29 \pm 0,75) \mathrm{cm}$; маса тіла - $(97,93 \pm 1,56)$ кг; IMT $(33,79 \pm 0,58) \kappa г / \mathbf{M}^{2}$. В подальшому всіх паціентів було розподілено на групи в залежності від IMT. Так, до 1 групи увійшло 22 особи із ЦД 2 типу з надлМТ - 11 чоловіків та 11 жінок. До II групи - 24 особи з ОЖ І ст. (15 чоловіків та 9 жінок); до III групи 18 осіб із ОЖ II ст. (10 чоловіків та 8 жінок) i IV групу склали 11 паціентів хворих на ЦД 2 типу з ОЖ III ст. (3 чоловіка та 8 жінок). Контрольну групу становили здорові особи із нормальною масою тіла -21 особа (9 чоловіків та 12 жінок). Антропометрична характеристика груп наведена в таблиці 1.

3 наведених даних таблиці видно, що хворі всіх груп були майже однакового віку, зросту і відрізнялися за масою тіла та IMT.

Ступінь ожиріння встановлювали згідно нової класифікації, яка була запропонована у 2013 році Американською асоціаціею спеціалістів в області клінічної ендокринології сумісно з Американською колегією ендокринологів, згідно з якими ожиріння

Антропометричні характеристики

обстежених паціентів ((M \pm m), p)

\begin{tabular}{|c|c|c|c|c|c|}
\hline Показник & $\begin{array}{c}\text { Контрольна } \\
\text { (нМТ), } \\
\text { n = 21 }\end{array}$ & $\begin{array}{c}\text { I група } \\
\text { (надл МТ), } \\
\text { n = 22 }\end{array}$ & $\begin{array}{c}\text { II група } \\
\text { (ОЖ I ст.), } \\
\text { n = 24 }\end{array}$ & $\begin{array}{c}\text { III група } \\
\text { (ОЖ II ст.), } \\
\text { n = 18 }\end{array}$ & $\begin{array}{c}\text { IV група } \\
\text { (ОЖ III ст.), } \\
\text { n = 11 }\end{array}$ \\
\hline Вік, рік & $68,19 \pm 2,25$ & $70,45 \pm 2,40$ & $66,08 \pm 2,41$ & $64,00 \pm 2,80$ & $69,36 \pm 3,89$ \\
\hline Зріст, см & $\begin{array}{c}167,10 \pm 1,72 \\
\mathrm{p}_{\mathrm{K}-\mathrm{II}}<0,05\end{array}$ & $\begin{array}{c}170,64 \pm 1,83 \\
\mathrm{p}_{\mathrm{I}-\mathrm{IV}}<0,05\end{array}$ & $172,04 \pm 1,71$ & $170,28 \pm 4,60$ & $164,90 \pm 1,99$ \\
\hline Маса тіла, кг & $\begin{aligned} & 65,05 \pm 1,89 \\
& \mathrm{p}_{\mathrm{K}-\mathrm{I}}<0,001 \\
& \mathrm{p}_{\mathrm{K}-\mathrm{II}}<0,001 \\
& \mathrm{p}_{\mathrm{K}-\mathrm{III}}<0,001 \\
& \mathrm{p}_{\mathrm{K}-\mathrm{IV}}<0,001\end{aligned}$ & $\begin{array}{c}76,83 \pm 1,42 \\
\mathrm{p}_{\mathrm{I}-\mathrm{II}}<0,001 \\
\mathrm{p}_{\mathrm{I}-\mathrm{III}}<0,001 \\
\mathrm{p}_{\mathrm{I}-\mathrm{IV}}<0,001\end{array}$ & $96,77 \pm 2,25$ & $108,17 \pm 2,13$ & $120,17 \pm 3,09$ \\
\hline IMT, кг/м ${ }^{2}$ & $\begin{array}{c}23,22 \pm 0,25 \\
\mathrm{p}_{\mathrm{K}-\mathrm{I}}<0,001 \\
\mathrm{p}_{\mathrm{K}-\mathrm{II}}<0,001 \\
\mathrm{p}_{\mathrm{K}-\mathrm{III}}<0,001 \\
\mathrm{p}_{\mathrm{K}-\mathrm{IV}}<0,001\end{array}$ & $\begin{array}{c}26,35 \pm 0,27 \\
\mathrm{p}_{\mathrm{I}-\mathrm{II}}<0,001 \\
\mathrm{p}_{\mathrm{I}-\mathrm{III}}<0,001 \\
\mathrm{p}_{\mathrm{I}-\mathrm{IV}}<0,001\end{array}$ & $32,54 \pm 0,26$ & $37,26 \pm 0,33$ & $44,18 \pm 0,89$ \\
\hline
\end{tabular}

Примітка.

$\mathrm{M} \pm \mathrm{m}$ - середне \pm стандартна помилка середнього;

$\mathrm{p}-$ значимість розходжень при порівнянні показників різних груп. 
було признано хронічним захворюванням зі специфічними ускладненнями. В основі збережено діагностику оцінки IMT, згідно з критеріями Всесвітньої організації охорони здоров'я (ВООЗ) та доповнено оцінкою фенотипу ожиріння та кардіометаболічного ризику $[39,40]$. IMT розраховували як відношення маси тіла у кілограмах до показника зросту у метрах, що зведений у квад-

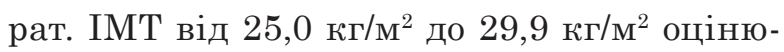
вали як надлишок маси тіла, від 30,0 кг/м² до $34,9 \mathrm{\kappa} / \mathrm{M}^{2}$ - як ожиріння I ступеня,

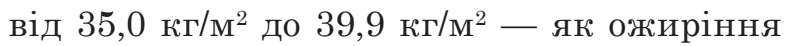
II ступеня, 40,0 та вище - як ожиріння III ступеня.

Вміст васпіну в сироватці крові хворих визначали методом імуноферментного аналізу з використанням набору реактивів Нuman/Mouse/Rat Vaspin Enzyme Immunoassay Kit виробництва фірми «RayBio ${ }^{\circledR}$ » (Грузія), рівень оментину - методом імуноферментного аналізу із використанням комерційної тест-системи Human Omentin-1 ELISA виробництва фірми «BioVendor» (Чеська Республіка).

Під час клінічного дослідження дотримувалися передбачених у таких випадках заходів безпеки для здоров'я паціента, захисту його прав, людської гідності та морально-етичних норм, відповідно до принципів Гельсінської декларації прав людини (1964), Конвенції Ради Європи про права людини і біомедицини, відповідних законів України, дозволу Комісії з медичної етики при Державній установі «Інститут проблем ендокринної патології ім. В. Я. Данилев- ського Національної академії медичних наук України».

Всі паціенти підписали інформовану згоду на участь у дослідженні.

Статистична обробка отриманих даних проведена за допомогою пакету статистичних програм "Statistica 8,0» (StatSoft Inc, США), Microsoft Office Excel-2003. Кількісні ознаки при нормальному розподілі були представлені у вигляді середне \pm стандартна помилка середнього ( $\mathrm{M} \pm \mathrm{m})$, для порівняння середніх двох вибірок використовували критерій Стьюдента. Оцінку відмінностей між групами при розподілі, близькому до нормального, проводили за допомогою критерію Пірсона.

Для виявлення наявності і сили зв'язку між фракторами вираховували ранговий коефіцієнт кореляції Спірмана $-r_{s}$. Високо значимою вважали кореляцію при $r_{s}$, який відповідає рівню статистичної значущості $\mathrm{p} \leq 0,01$, значимою - при $r_{s}$, що відповідає рівню статистичної значущості $\mathrm{p} \leq 0,05$, про тенденцію достовірного зв'язку говорили при $r_{s}$, який відповідае рівню статистичної статистичної значущості $\mathrm{p} \leq 0,1$. Використовували наступну класифікацію кореляційного зв'язку:

1) сильний $\left(0,7<r_{s}<1\right)$;

2) середньої сили $\left(0,5<r_{s}<0,7\right)$;

$3)$ помірний $\left(0,3<r_{s}<0,5\right)$;

4) слабкий $\left(0,2<r_{s}<0,3\right)$.

При $r_{s}<0,11$ вважали, що кореляція відсутня. Довірчі інтервали були в межах $95 \%$, різниця досліджуваних параметрів вважалася істотною при $\mathrm{p} \leq 0,05$.

\section{РЕЗУЛЬТАТИ ТА ЇХ ОБГОВОРЕННЯ}

Було проведено дослідження рівнів адипокінів - васпіну та оментину у хворих на ЦД 2 типу в залежності від ступеня ожиріння задля встановлення їх ролі в подальшому розвитку та прогресуванні серцево-судинних ускладнень у вищезазначених хворих.

Як видно з наведених даних, концентрація васпіну сироватки крові у осіб з ожирінням різного ступеню була достеменно вища у порівнянні з особами із надлишковою масою тіла та контрольною групою, $\mathrm{p}<0,001$.
Щодо концентрації оментину в сироватці крові у групах хворих на ЦД 2 типу з ожирінням різного ступеня $(377,66 \pm 8,73)$, $(373,08 \pm 10,6)$ i $(375,26 \pm 17,44)$ нг/мл, відповідно, то вона була навпаки достовірно зниженою у порівнянні з особами з надлишковою масою тіла та контрольною групою $(465,17 \pm 7,47)$ і $(465,17 \pm 7,47)$ нг/мл, відповідно, $\mathrm{p}<0,001$. Слід зазначити, що аналогічні дані були отримані De Souza Batista et al. у 2007 p., які повідомили, що експресія оментину в вісцеральній жировій тканині та сироватці крові були значно нижчими 
Рівні адипокінів у обстежених осіб в залежності від наявності або відсутності ожиріння, $((\mathbf{M} \pm \mathbf{m}), \mathbf{p})$

\begin{tabular}{|c|c|c|c|c|c|}
\hline Показник & $\begin{array}{c}\text { Контрольна } \\
\text { (нМT), } \\
\text { n = 21 }\end{array}$ & $\begin{array}{c}\text { I група } \\
\text { (надл МT), } \\
\text { n = 22 }\end{array}$ & $\begin{array}{c}\text { II група } \\
\text { (ОЖ I ст.), } \\
\text { n = 24 }\end{array}$ & $\begin{array}{c}\text { III група } \\
\text { (ОЖ II ст.), } \\
\text { n = } 18\end{array}$ & $\begin{array}{c}\text { IV група } \\
\text { (ОЖ⿱ III ст.), } \\
\text { n = 11 }\end{array}$ \\
\hline $\begin{array}{c}\text { Васпін, } \\
\text { пг/мл }\end{array}$ & $\begin{array}{c}523,12 \pm 14,87 \\
\mathrm{p}_{\mathrm{K}-\mathrm{II}}<0,001 \\
\mathrm{p}_{\mathrm{K}-\mathrm{III}}<0,001 \\
\mathrm{p}_{\mathrm{K}-\mathrm{IV}}<0,001\end{array}$ & $\begin{aligned} 527,87 & \pm 18,11 \\
\mathrm{p}_{\mathrm{I}-\mathrm{II}} & <0,001 \\
\mathrm{p}_{\mathrm{I}-\mathrm{III}} & <0,001 \\
\mathrm{p}_{\mathrm{I}-\mathrm{IV}} & <0,001\end{aligned}$ & $674,78 \pm 17,57$ & $683,89 \pm 21,94$ & $679,98 \pm 32,56$ \\
\hline $\begin{array}{c}\text { Оментин, } \\
\text { нг/мл }\end{array}$ & $\begin{aligned} 465,17 & \pm 7,47 \\
\mathrm{p}_{\mathrm{K}-\mathrm{II}} & <0,001 \\
\mathrm{p}_{\mathrm{K} \text {-III }} & <0,001 \\
\mathrm{p}_{\mathrm{K}-\mathrm{IV}} & <0,001\end{aligned}$ & $\begin{array}{c}465,17 \pm 7,47 \\
\mathrm{p}_{\text {IIII }}<0,001 \\
\mathrm{p}_{\text {I-III }}<0,001 \\
\mathrm{p}_{\text {I-IV }}<0,001\end{array}$ & $377,66 \pm 8,73$ & $373,08 \pm 10,6$ & $375,26 \pm 17,44$ \\
\hline
\end{tabular}

Примітка.

$\mathrm{M} \pm \mathrm{m}$ - середне \pm стандартна помилка середнього;

$\mathrm{p}-$ значимість розходжень при порівнянні показників різних груп.

Кореляційні взаємозв'язки

Таблиця 3 між рівнем васпіну та антропометричними параметрами у обстежених осіб

\begin{tabular}{|c|c|c|c|c|c|c|c|c|c|c|}
\hline \multirow[t]{2}{*}{$\begin{array}{c}\text { Показ- } \\
\text { ник }\end{array}$} & \multicolumn{2}{|c|}{$\begin{array}{c}\text { Контрольна } \\
\text { (нМТ), } \\
\text { n = 21 }\end{array}$} & \multicolumn{2}{|c|}{$\begin{array}{c}\text { I група } \\
\text { (надл МT), } \\
\text { n = 22 }\end{array}$} & \multicolumn{2}{|c|}{$\begin{array}{c}\text { II група } \\
\text { (ОЖ I ст.), } \\
\text { n = 24 }\end{array}$} & \multicolumn{2}{|c|}{$\begin{array}{c}\text { III група } \\
\text { (ОЖ II ст.), } \\
\text { n = } 18\end{array}$} & \multicolumn{2}{|c|}{$\begin{array}{c}\text { IV група } \\
\text { (ОЖ⿱ III ст.), } \\
\text { n = 11 }\end{array}$} \\
\hline & $\mathbf{r}_{\mathrm{s}}$ & p & $\mathbf{r}_{\mathrm{s}}$ & p & $\mathbf{r}_{\mathrm{s}}$ & p & $\mathbf{r}_{\mathrm{s}}$ & p & $\mathbf{r}_{\mathrm{s}}$ & p \\
\hline $\mathrm{OT}, \mathrm{cm}$ & $-0,65$ & $<0,001$ & $-0,50$ & $<0,05$ & $-0,70$ & $<0,001$ & $-0,44$ & $<0,05$ & $-0,29$ & н/д \\
\hline $\mathrm{OC}, \mathrm{cm}$ & 0,64 & $<0,001$ & 0,42 & $<0,05$ & $-0,11$ & н/д & 0,17 & н/д & $-0,27$ & н/д \\
\hline ЖМ, кг & 0,54 & $<0,01$ & $-0,12$ & н/д & $-0,24$ & н/д & $-0,26$ & н/д & $-0,55$ & $<0,05$ \\
\hline 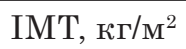 & 0,18 & н/д & $-0,24$ & н/д & 0,05 & н/д & $-0,02$ & н/д & $-0,66$ & $<0,05$ \\
\hline
\end{tabular}

Прилітки:

rs - ранговий коефіціент кореляції Спірмана;

p - значущість відмінностей показників.

у осіб з надлишковою масою тіла та ожирінням, порівняно з особами з нормальною вагою тіла [19].

Спираючись на попередні дослідження [17, 19-21, 23] нами були простежені кореляційні зв'язки рівнів васпіну та оментину з параметрами ожиріння, а саме обводом талії (ОТ), обводом стегон (ОС), жировою масою та IMT (табл. 3, 4).

В результаті аналізу виявлених кореляційних взаємозв'язків встановлено, що рівень васпіну у хворих на ЦД 2 типу з ожирінням різного ступеня вірогідно $(\mathrm{p}<0,05)$ зворотно корелював з показниками ОТ (сильний зв'язок), ОС (помірний зв'язок), вЖМ (зв'язок середньої сили), а рівень оментину навпаки з вищезазначеними по- казниками у хворих на ЦД 2 типу з ожирінням різного ступеня корелював позитивно (iз сильною, помірною та середньою силою відповідно, p < 0,05). У осіб з надлишковою масою тіла кореляційні взаємозв'язки помірної сили простежувались між рівнем васпіну та ОT, ОС. Але направленість їх була протилежною: між рівнем васпіну та ОТ - прямою, а між рівнем васпіну та OC - зворотною. Рівень оментину та вищезазначені показники (ОТ, ОС) також мали між собою помірний вірогідний кореляційний зв'язок аналогічної спрямованості. У осіб контрольної групи рівень васпіну зворотно вірогідно корелював с показником ОТ і позитивно з ОС та рівнем, відповідно, p $<0,001$ та $<0,01)$, а рівень оментину - 
Кореляційні взаемозв'язки між рівнем оментину та антропометричними параметрами у обстежених осіб

\begin{tabular}{|c|c|c|c|c|c|c|c|c|c|c|}
\hline \multirow[t]{2}{*}{$\begin{array}{c}\text { Показ- } \\
\text { ник }\end{array}$} & \multicolumn{2}{|c|}{$\begin{array}{c}\text { Контрольна } \\
\text { (нМT), } \\
\text { n = 21 }\end{array}$} & \multicolumn{2}{|c|}{$\begin{array}{c}\text { I група } \\
\text { (надл MT), } \\
\text { n = 22 }\end{array}$} & \multicolumn{2}{|c|}{$\begin{array}{c}\text { II група } \\
\text { (ОЖ I ст.), } \\
\text { n = 24 }\end{array}$} & \multicolumn{2}{|c|}{$\begin{array}{c}\text { III група } \\
\text { (ОЖ II ст.), } \\
\text { n= 18 }\end{array}$} & \multicolumn{2}{|c|}{$\begin{array}{c}\text { IV група } \\
\text { (ОЖ III ст.), } \\
\text { n = 11 }\end{array}$} \\
\hline & $\mathbf{r}_{\mathrm{s}}$ & $\mathbf{p}$ & $\mathbf{r}_{\mathrm{s}}$ & $\mathbf{p}$ & $\mathbf{r}_{\mathrm{s}}$ & $\mathbf{p}$ & $\mathbf{r}_{\mathrm{s}}$ & $\mathbf{p}$ & $\mathbf{r}_{\mathrm{s}}$ & $\mathbf{p}$ \\
\hline OT, см & 0,67 & $<0,001$ & 0,49 & $<0,05$ & 0,72 & $<0,001$ & 0,45 & $<0,05$ & 0,30 & н/д \\
\hline $\mathrm{OC}, \mathrm{cm}$ & $-0,61$ & $<0,01$ & $-0,46$ & $<0,05$ & 0,13 & н/д & $-0,15$ & & 0,28 & н/д \\
\hline ЖМ, кг & $-0,54$ & $<0,01$ & 0,04 & н/Д & 0,28 & н/д & 0,28 & & 0,55 & $<0,05$ \\
\hline 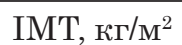 & $-0,14$ & н/д & 0,18 & н/д & $-0,05$ & н/д & 0,04 & & 0,66 & $<0,05$ \\
\hline
\end{tabular}

Примітки:

rs - ранговий коефіціент кореляції Спірмана;

p - значущість відмінностей показників.

позитивно корелював з показником ОТ $(\mathrm{p}<0,001)$ і негативно з показниками ОС та ЖМ (відповідно, $\mathrm{p}<0,01$ та $\mathrm{p}<0,01$ ). Сила даних зв'язків була помірною.

Таким чином, наведені результати дослідження засвідчують важливу роль васпіну та оментину в розвитку метаболічних порушень і відкривають нові можливості застосування вказаних адипокінів як прогностичних маркерів серцево-судинних захворювань у хворих на ЦД 2 типу.

Проведення аналізу даних літератури та власних результатів дослідження демонструють, що натепер залишаються дискутабельними питання механізмів впливу даних адипокінів на ступінь чутливості периферичних тканини до інсуліну. Потребуе додаткового дослідження характер зв'язку між секрецією васпіну, оментину та змінами геометрії серця, її систолічної та діастолічної функції, процесами формування атеросклеротичної бляшки.

Вимагае підтвердження та пояснення той факт, що рівні васпіну та оментину ма- ють різний характер зв’язку між ступенем накопичення жирової тканини на передній брюшній стінці та в глютеофеморальному жировому депо.

Наявність цілої низки невирішених питань щодо значення васпіну та оментину у розвитку ожиріння - предиктора серцево-судинних ускладнень у хворих на ЦД 2 типу обумовило проведення дослідження науковцями ДУ «Інститут проблем ендокринної патології ім. В. Я. Данилевського НАМН України».

Вирішення вищезазначених питань в його процесі дасть змогу вивчити біологічні і патофізіологічні ефекти васпіна та оментина в організмі людини, уточнити їх прогностично-діагностичне значення у хворих на ЦД 2 типу із серцево-судинної патологією на тлі ожиріння, що, на думку авторів, дасть змогу оптимізувати діагностично-лікувальні алгоритми для цієї категорії пацієнтів.

\section{ВИСНОВКИ}

1. Встановлено зворотний кореляційний зв'язок васпіну з показниками обводу талії, жировою масою, IMT $\left(\mathrm{r}_{\mathrm{s}}=-0,70 ;-0,44\right.$; $-0,55$ та - 0,66, відповідно, $\mathrm{p}<0,05)$.

2. Визначено прямий кореляційний зв'язок оментину з обводом талії, жировою масою та IMT у хворих на ЦД 2 типу в залеж- ності від ступеня ожиріння $\left(\mathrm{r}_{\mathrm{s}}=0,72 ; 0,45\right.$; 0,55 та 0,66, відповідно, $\mathrm{p}<0,05)$.

3 . Васпін та оментин можуть застосовуватися в якості прогностичних маркерів серцево-судинних ускладнень у хворих на ЦД 2 типу. 


\section{ЛІТЕРАТУРА \\ (REFERENCES)}

1. Bray G. A. J Clin Endocrinol Metab 2004; 89: 25832589. doi: https://doi.org/10.1210/jc.2004-0535.

2. Rabe K, Lehrke M, Parhofer KG, et al. Mol Med 2008; 14: 741-751. doi: 10.2119/2008-00058.Rabe.

3. Flehmig G, Scholz M, Klöting N, et al. PLoS One 2014; 9: e99785. doi: 10.1371/journal.pone.0099785.

4. Guvenc Y, Var A, Goker A, et al. J Int Med Res 2016; 44: 796-805. doi: 10.1177/0300060516645421.

5. Klöting N, Berndt J, Kralisch S, et al. Biochem Biophys Res Commun 2006; 339: 430-436. doi: 10.1016/j.bbrc. 2005.11.039

6. Hida K, Wada J, Eguchi J, et al. Proc Natl Acad Sci USA 2005; 102: 10610-10615. doi: https://doi.org/10. 1073/pnas.0504703102.

7. Youn BS, Klöting N, Kratzsch J, et al. Diabetes 2008; 57: 372-377. doi: 10.2337/db07-1045.

8. Suleymanoglu S, Tascilar E, Pirgon O, et al. Diabetes Res Clin Pract 2009; 84: 325-328. doi: 10.1016/j.diabres.2009.03.008.

9. Saalbach A, Tremel J, Herbert D, et al. Am J Pathol 2016; 186: 639-651. doi: https://doi.org/10.1016/ j.ajpath. 2015.10.030

10. Li HL, Peng WH, Cui ST, et al. Clin Chem Lab Med 2011; 49: 1547-1554. doi: 10.1515/CCLM.2011.236.

11. Villareal DT, Chode S, Parimi N, et al. $N$ Engl J Med 2011; 364: 1218-1229. doi: 10.1056/NEJMoa1008234.

12. Fasshauer M, Bluher M. Trends Pharmacol Sci 2015; 36: 461-470. doi: https://doi.org/10.1016/ j.tips.2015.04.014.

13. Wada J. Rinsho Byori 2008; 56: 705-711.

14. Hao F, Zhang H, Zhu J, et al. Diabetes Res Clin Pract 2016;113: 26-32. doi: 10.1016/j.diabres.2015.12.001.

15. Misjura KV, Kravchun PP. Mizhnar Endokrynol Zhurn 2017; 13(4): 22-27. doi: 10.22141/2224-0721.13.4.2017. 106648 .

16. Dalia H. El-Lebedy, Alshaymaa A I., Ashmawy I. O. Diabetes Metab Syndr 2018; 12(5): 643-648. doi: 10.1016/j.dsx.2018.04.025.

17. Pan HY, Guo L, Li Q. Diabetes Res Clin Pract 2010; 88: 29-33. doi: 10.1016/j.diabres.2010.01.013.

18. Tan BK, Adya R, Farhatullah S, et al. Diabetes 2008; 57: 801-808. doi: 10.2337/db07-0990.

19. de Souza Batista CM, Yang RZ, Lee MJ, et al. Diabetes 2007; 56: 1655-1661. doi: 10.2337/db06-1506.

20. Yan P, Liu D, Long M, et al. R Li Exp Clin Endocrinol Diab 2011; 119: 257-263. doi: 10.1055/s-0030-1269912.

21. Xu T, Zuo P, Cao L, et al. Thromb J 2018; 25(6): 505511. doi: https://doi.org/10.5551/jat.42135.
22. Escoté X, Gómez-Zorita S, López-Yoldi M, et al. Int $J$ Mol Sci 2017; 18(8): 1770. doi: 10.3390/ijms18081770.

23. Yoo HJ, Hwang SY, Hong HC, et al. Diabetology 2011; 10: 103. doi: 10.1186/1475-2840-10-103.

24. Misjura KV, Kravchun PP. Klinichna endokrynologija ta endokrynna hirurgija 2017; 3(59): 60-68. doi: https:// doi.org/10.24026/1818-1384.3(59).2017.110906.

25. Ji-Yin Zhou, Lawrence Chan, Shi-Wen Zhou Curr. Vasc Pharmacol 2014; 12(1): 136-143. doi: 10.2174/157016111 2999140217095038 .

26. Kravchun PG, Kravchun PP. Medicina 2015; 1(151): 5-9, available at: http://repo.knmu.edu.ua/ handle/ 123456789/9046.

27. Shibata R, Ouchi N, Kikuchi R, et al. Atherosclerosis 2011; 219: 811-814. doi: 10.1016/j.atherosclerosis. 2011. 08.017.

28. Zhong X, Zhang HY, Tan H, et al. Acta Pharmacol Sin 2011; 32: 873-878. doi: 10.1038/aps.2011.26.

29. Kadoglou NP, Lambadiari V, Gastounioti A, et al. Atherosclerosis 2014; 235: 606-612. doi: 10.1016/j.atherosclerosis.2014.05.957.

30. Moreno-Navarrete JM, Ortega F, Castro A, et al. Obesity 2011; 19(8): 1552-1559. doi: 10.1038/oby.2010.351.

31. Shibata R, Takahashi R, Kataoka Y, et al. Hypertens Res 2011; 34: 1309-1312. doi: 10.1038/hr.2011.130.

32. Hayashi M, Morioka T, Hatamori M, et al. Clin Pract 2019; 148: 160-168. doi: 10.1016/j.diabres.2019.01.009.

33. Maruyama S, Shibata R, Kikuchi R, et al. J Biol Chem 2012; 287: 408-417. doi: 10.1074/jbc.M111.261818.

34. Wang Y, Sun M, Wang Z, et al. Biophys Res Commun 2018;498: 152-156. doi: 10.1016/j.bbrc.2018.02.012.

35. Yamawaki H, Tsubaki N, Mukohda M, et al. Res Commun 2010; 393: 668-672. doi: 10.1016/j.bbrc.2010.02.053.

36. Uemura Y, Shibata R, Kanemura N, et al. FASEB $J$ 2015; 29: 141-151. doi: 10.1096/fj.14-258129.

37. Hiramatsu-Ito M, Shibata R, Ohashi K, et al. Cardiovasc Res 2016; 110: 107-117. doi: 10.1093/cvr/cvv282.

38. Kataoka Y, Shibata R, Ohashi K, et al. J Am Coll Cardiol 2014; 63: 2722-2733. doi: 10.1016/j.jacc.2014. 03.032 .

39. Garvey W, Garber AJ, Mechanick JI, et al. Endocr Pract 2014; 20(9): 977-989. doi: 10.4158/EP14280.PS.

40. World Health Organization. Obesity and Overweight. Factsheet. WHO Media Centre, available at: https:// www.who.int/ru/news-room/fact-sheets/ detail/obesityand-overweight. 


\section{ЗНАЧЕННЯ ВАСПІНУ ТА ОМЕНТИНУ У РОЗВИТКУ ОЖИРІННЯ - ПРЕДИКТОРА СЕРЦЕВО-СУДИННИХ УСКЛАДНЕНЬ У ХВОРИХ НА ЦУКРОВИЙ ДІАБЕТ 2 ТИПУ}

Кравчун Н. О. ${ }^{1}$, Алхамід М. Х. ${ }^{1}$, Місора К. В. ${ }^{1}$, Дунаева I. П. ${ }^{2}$, Романова І. П. ${ }^{1}$, Чернявська I. В. ${ }^{1}$, Соколова С. С. ${ }^{1}$

${ }^{1}$ ДУ «Інститут проблем ендокринної патологї̈ іл. В. Я. Данилевського НАМН Украӥни», м. Харків, Україна;

${ }^{2}$ Харківський національний медичний університет, м. Харків, Украйна vladimirovana59@gmail.com

Метою проведеної роботи стало з'ясування значення васпіну та оментину при метаболічних зсувах, ендотеліальній дисфункції, серцево-судинних захворюваннях та інших судинних порушеннях у хворих на цукровий діабет 2 типу на підставі аналізу сучасних літературних джерел та власних досліджень.

Матеріал та методи. Проведений ретельний огляд сучасних літературних джерел, що включав результати клінічних та експериментальних даних, щодо досліджень значення гормонів васпіну й оментину в розвитку серцево-судинних ускладнень у хворих на цукровий діабет 2 типу на тлі ожиріння. Проведено обстеження 75 паціентів із цукровим діабетом 2 типу з надлишковою масою тіла та ожирінням різного ступеня. Визначено рівні васпіну та оментину в сироватці крові. Наявність і силу зв'язку між факторами вираховували ранговим коефіціентом кореляції Спірмана $-r$ s

В результаті аналізу літературних даних встановлено, що на сучасному етапі біологічні і патофізіологічні ефекти васпіну та оментину в організмі людини до кінця не з'ясовані, а даних щодо їх прогностично-діагностичного значення у хворих на цукровий діабет 2 типу із серцево-судинної патологією на тлі ожиріння вкрай мало, тому при вивченні власних даних щодо з'ясування ролі цих адипокінів в розвитку метаболічних порушень, а саме, ожиріння різного ступеню, як предиктора серцево-судинних ускладнень у вищевказаних хворих, доведено зворотний кореляційний зв'язок васпіну з показниками обводу талії, жировою масою і індексом маси тіла та прямий - з обводом стегон. Щодо оментину, то отримано дані, які свідчать про наявність прямого кореляційного зв'язку між даним адипокіном та обводом талії, жировою масою і індексом маси тіла, зворотного - з обводом стегон. Також висловлено припущення, що ці адипокіни можуть застосовуватися в якості прогностичних маркерів серцево-судинних ускладнень у вищевказаних осіб.

Зроблено висновок, що васпін та оментин відіграють важливу роль в розвитку метаболічних порушень, але потребують ще подальших досліджень.

К л ючові с лов а: васпін, оментин, цукровий діабет 2 типу, ожиріння, серцево-судинні захворювання.

\section{THE SIGNIFICANCE OF VASPIN AND OMENTIN IN THE DEVELOPMENT OF OBESITY - A PREDICTOR OF CARDIOVASCULAR COMPLICATIONS IN PATIENTS WITH TYPE 2 DIABETES \\ Kravchun N. A. ${ }^{1}$, Alhamid M. H. ${ }^{1}$, Misyura K. V. ${ }^{1}$, Dunaieva I. P. ${ }^{2}$, Romanova I. P. ${ }^{1}$, Chernyavska I. V. ${ }^{1}$, Sokolova S. S. \\ ${ }^{1} S I$ «V. Danilevsky Institute for endocrine pathology problems National Academy of Medical sciences of Ukraine», Kharkiv, Ukraine; \\ ${ }^{2}$ Kharkiv national medical University, Kharkiv, Ukraine vladimirovana59@gmail.com}

The aim of the work was to find out the significance of vaspin and omentin in metabolic shifts, endothelial dysfunction, cardiovascular diseases and other vascular disorders in patients with type 2 diabetes mellitus based on the analysis of modern literature sources and their own research.

Material and methods. A thorough review of modern literature sources, including the results of clinical and experimental data, on studies of the importance of the hormones vaspin and omentin in the development of cardiovascular complications in patients with type 2 diabetes mellitus against the background of obesity, was carried out. 75 patients with type 2 diabetes mellitus, overweight and obese of varying degrees were examined. Serum vaspin and omentin levels were determined. The presence and strength of the relationship between factors were calculated using the Spearman $-r_{\mathrm{s}}$ rank correlation coefficient.

As a result of the analysis of literature data, it was found that at the present stage, the biological and pathophysiological effects of vaspin and omentin in the human body are not fully clarified, and data on their prognostic and diagnostic value in patients with type 2 diabetes mellitus with cardiovascular pathology against the background of obesity are extremely small, so when studying their own data on finding out the role of these adipokines in the development of metabolic disorders, namely, obesity of varying degrees, as a predictor of cardiovascular complications in the above patients, the inverse correlation of vaspin with waist circumference indicators is proved, fat mass and body mass index and straight-with the outline of the hips. As for omentin, data were obtained that indicate the presence of a direct correlation between this adipokin and waist circumference, fat mass and body mass index, the opposite - with hip circumference. It has also been suggested that these adipokines can be used as prognostic markers of cardiovascular complications in the above individuals.

It is concluded that vaspin and omentin play an important role in the development of metabolic disorders, but require further research.

Key words: vaspin, omentin, type 2 diabetes mellitus, obesity, cardiovascular diseases. 